\title{
Mercury and trace element distribution in density separates of a South African Highveld (\#4) coal: Implications for mercury reduction and preparation of export coal
}

\author{
Allan Kolker ${ }^{1}$, Constance Senior ${ }^{2}$, Chris van Alphen $^{3}$, Alan Koenig ${ }^{4}$, and Nick Geboy ${ }^{1}$ \\ ${ }^{1}$ U.S. Geological Survey, Mail Stop 956, National Center, Reston, Virginia, USA \\ ${ }^{2}$ ADA Environmental Solutions, Inc., Highlands Ranch, Colorado, USA \\ ${ }^{3}$ Eskom Holdings SOC Ltd., Johannesburg, South Africa \\ ${ }^{4}$ U.S. Geological Survey, Mail Stop 973, Denver Federal Center, Denver, Colorado, USA
}

\begin{abstract}
Eight density separates of Permian Highveld (\#4) coal were investigated for partitioning of $\mathrm{Hg}$ and trace elements. The separates include float fractions obtained in heavy media having densities of $1.4,1.5,1.6,1.7,1.8,1.9$, and $2.0 \mathrm{~g} / \mathrm{cm}^{3}$, and the sink fraction for $2.0 \mathrm{~g} / \mathrm{cm}^{3}$. Bulk analysis of the separates shows strong $\left(R^{2} \geq 0.80\right)$ positive correlations between pyritic sulfur and mercury, and between ash yield and both pyritic sulfur and mercury. Laser ablation (LA) ICP-MS analysis of individual pyrite grains in the separates confirms association of $\mathrm{Hg}$ and As with pyrite as indicated by bulk analysis. Other elements detected in pyrite by LA-ICP-MS include as $\mathrm{Mn}, \mathrm{Co}, \mathrm{Ni}, \mathrm{Tl}$, and $\mathrm{Pb}$. Results for the separates allow prediction of $\mathrm{Hg}$, trace elements, and ash yields expected in specific South African coal products. These range from $0.06 \mathrm{ppm} \mathrm{Hg}$ and an ash yield of $11.5 \%$ ash for the export fraction to $0.47 \mathrm{ppm} \mathrm{Hg}$ and an ash yield of $60.9 \%$ for the discard (stone) fraction (dry basis). Results show pronounced differences expected between coal used for domestic power generation and coal which is exported.
\end{abstract}

Keywords: Mercury; trace elements; coal; South Africa; pyrite; laser ablation ICP-MS 


\section{Introduction}

South Africa is the world's seventh largest coal producer (in 2013) and a major global coal exporter (World Coal Association, 2014). South Africa relies on coal for more than $90 \%$ of its electric power generation (in 2012), which is among the highest proportions in the world (World Coal Association, 2014). Eskom is the national electric utility, supplying about $95 \%$ of the electricity used in South Africa, and $40 \%$ of the electricity on the African continent (Eskom, 2014). The remaining capacity is almost entirely coal-based, including power generation for internal use by industrial operators such as Sasol, and several small independent power producers (Scott, 2011). The Eskom fleet includes thirteen operating coal-fired power stations, with two larger stations, Medupi and Kusile, under construction (Eskom, 2014).

Despite the prominence of South Africa as a producer and user of coal for power generation, the ability to predict emissions of mercury from the domestic utility sector has been limited by a need to assume the mercury contents of South African coals (Dabrowski et al., 2008; Leaner et al., 2009; Masekoameng et al., 2010). Measurements of speciated Hg emissions from two Eskom power stations, Kendal and Duvha, were obtained over a brief period in 2010, in collaboration with the U.S. EPA (Scott, 2011). For the other power stations, there are no direct emissions determinations for mercury. Estimates of emitted mercury for the South African utility sector have been obtained by assuming mercury contents in South African feed coals and applying fixed emission factors (Pacyna et al., 2006; Dabrowski et al., 2008, Leaner et al., 2009; Masekoameng et al., 2010; AMAP/UNEP, 2013). Early on, this approach likely over estimated emissions as little was known about the mercury content of South African coals and a wide concentration range was estimated (Pacyna et al. 2006). More 
recent estimates generally give lower emissions totals, but are still based on rather limited sampling (Dabrowski et al., 2008, Leaner et al., 2009; Masekoameng et al., 2010).

To better understand the distribution of $\mathrm{Hg}$ in coals used for electric power generation in South Africa, the United Nations Environment Programme (UNEP) supported a reconnaissance study of two to four samples of feed coal from each of the thirteen Eskom power stations (Kolker et al., 2014), and a concurrent investigation of density separates of Highveld (\#4) coal representing feedstock for both domestic power generation and washed export coal (this study). Power station feed coals utilized by Eskom typically include all but a fraction prepared for export and a high-ash discard fraction. In some cases, Eskom may also burn unwashed runof-mine coal, or a de-stoned product from which only the discard fraction has been removed.

Permian (Gondwanan) coals of the southern hemisphere generally have low sulfur and halogen contents, and high ash yields compared to Carboniferous coals of the northern hemisphere (Falcon, 1986; Wagner and Hlatshwayo, 2005). Coal production in South Africa is concentrated primarily in the Highveld region of Mpumalanga Province where the Witbank, Highveld, and Ermelo coals supply the majority of Eskom power stations and provide feedstock for Sasol's coal-to-liquids operations. The Witbank and Highveld coals are laterally contiguous, with the \#2, \#4, and \#5 coals being the major coal beds produced in each (Falcon, 1986; Caincross et al., 1990; Pretorius et al., 2002, Hancox and Götz, 2014). The Witbank \#2 coal has been an important source of low ash, washed export coal whereas the lower quality Witbank and Highveld \#4 coals are important for domestic power generation. As supplies of Witbank and Highveld \#2 coals are declining, the Highveld \#4 coal is increasingly important as feedstock for washed export product (Bergh et al., 2011; Hancox and Götz, 2014). Compared to the \#2 
and \#4 coals, the \#5 coal is relatively thin, but it has been an important source of metallurgical coal (Jeffrey, 2005).

Domestic use of washed coal for power generation in South Africa is limited to Waterberg coals in Limpopo Province. Coal washing is needed for Waterberg coals because of finely laminated mudstone present within these coals (Jeffrey, 2005; Wagner and Tlotleng, 2012). Waterberg coals are important because large reserves are present, and this may help offset declining production in the Highveld region. Washed Waterberg coal currently supplies Eskom's Matimba power station in Limpopo Province, and will supply the 4,764 MW Medupi station under construction nearby. The second new coal-fired power station, the 4,800-MW Kusile station under construction in Mpumalanga Province, will presumably utilize Witbank/Highveld coals.

\section{Previous work}

Five run-of-mine samples and a middlings split of Highveld \#4 coal were studied by Wagner and Hlatshwayo (2005) for determination of potentially hazardous elements. These authors determined mean mercury contents for multiple analyses of each these six samples ranging from 0.10 to $0.23 \mathrm{ppm}$ (whole coal basis), which compares to the global average $(0.10 \mathrm{ppm} \mathrm{Hg}$; Yudovich and Ketris, 2005; Ketris and Yudovich, 2009), as well as the in-ground mean for Hg in U.S. coals (0.17 ppm) obtained in USGS sampling (Bragg et al., 1998), and the mean for $\mathrm{Hg}$ in Chinese coals (0.16 ppm; Dai et al., 2012). Wagner and Hlatshwayo (2005) also showed that Highveld coals are notably enriched in $\mathrm{Cr}$ and $\mathrm{Mn}$, and depleted in As and $\mathrm{Sb}$, relative to global averages (Ketris and Yudovich, 2009). 
Bergh et al. (2011) compared froth flotation and density separation approaches to trace element reduction for a Witbank \#4 coal with a reported mercury content of $0.3 \mathrm{ppm}$, and concluded that the density separation approach is more effective for pyrite-associated elements such as Hg. Wagner and Tlotleng (2012) used a similar density separation approach to investigate the distribution of trace elements in separates of South African Waterberg coals. Overall, this study found a good correlation of $\mathrm{Hg}$ (and As) with pyrite (from pyritic sulfur), with the exception of one sample from the Vryheid Formation (Wagner and Tlotleng, 2012).

\section{Materials and Methods}

Eight laboratory density separates of a Highveld (\#4) coal were prepared by Eskom to investigate the quality of washed coal and the distribution of mercury and trace elements expected in the washed coal and the remaining fractions. The density separates consist of 1 $\mathrm{mm}$ size fractions generated in heavy media ranging in density from 1.4 to $2.0 \mathrm{~g} / \mathrm{cm}^{3}$, including float fractions for densities $1.4,1.5,1.6,1.7,1.8,1.9$, and $2.0 \mathrm{~g} / \mathrm{cm}^{3}$, designated samples $1.4 \mathrm{~F}$ to

2.0F, and the sink fraction for $2.0 \mathrm{~g} / \mathrm{cm}^{3}$ (sample 2.0S; Table 1). Polished mounts were prepared for microanalysis of each density separate and the samples were powdered in an agate mortar for bulk analysis.

Analyses by a commercial laboratory (Geochemical Testing, Inc., Somerset, PA, USA) included short proximate (ash, sulfur, moisture, calorific value), sulfur forms, and halogens, using ASTM methods as follows (Table 1). In brief, moisture (method D3302) and ash-yield (method D3174) were determined by mass balance following drying and combustion, respectively, of a known mass of coal sample. Calorific value (method D5865) was measured 
using a calibrated adjustment to a calorimeter, whereas total sulfur (method D4239) was measured as $\mathrm{SO}_{2}$ (g) using IR spectrometry following combustion. Forms of sulfur (method D2492) include sulfate, sulfide and organic forms. Sulfate $S$ was determined gravimetrically following extraction via dilute $\mathrm{HCl}$. Sulfide $\mathrm{S}$ is assumed to be dominantly pyritic and was therefore calculated as a stoichiometric combination with Fe. Organic $S$ is a calculated parameter, determined by subtraction of sulfate and sulfide $S$ from the total sulfur measured above. Halogens ( $\mathrm{Cl}$, and $\mathrm{F}$ ) were determined in solution using ion-specific electrodes, according to ASTM methods D4208 and D3761, respectively (ASTM, 2014).

Mercury contents were determined at the USGS Eastern Energy Resources Science Center in Reston, Virginia, using a Nippon MA-3000 instrument, with replicate analyses obtained at USGS Central Energy Resources labs in Denver, Colorado, using a Milestone DMA-80 instrument. Each instrument employs EPA Method 7473, in which samples are heated and the evolved $\mathrm{Hg}$ is selectively captured as an amalgam and measured by atomic absorption spectrophotometry (U.S. Environmental Protection Agency, 2007). Comparison of values obtained using the Reston and Denver instruments shows agreement within $20 \%$ or better in almost all cases. Exceptions converge after a few runs, and there are no systematic differences in results from the two labs (Appendix 1 in Kolker et al., 2014).

Trace element data for the separates were determined by a commercial lab using ICP-MS (Actlabs, Ancaster, Ontario, Canada). As an internal check, the same sample powders were determined by ICP-MS at USGS labs in Denver. Trace element results by ICP-MS given in Table 2 reflect values obtained from Actlabs, with the exception of $\mathrm{Cr}$, As, and $\mathrm{Sb}$. For these three elements, results from USGS Labs are used due to the potential for volatilization and loss of 
these elements in the Actlabs digestion procedure. A comparison of trace element results by Actlabs and by the USGS for the same sample powders is given by Kolker et al., 2014. Prior to analysis, in each lab bulk samples for ICP-MS were combusted at $525^{\circ} \mathrm{C}$ for $36 \mathrm{~h}$ and the resulting ash was digested in heated multi-acid mixtures. Ash yields and moisture determinations used to convert results obtained on an ash basis to a dry whole coal basis are given in Table 1. For ICP-MS determinations, combustion at $525^{\circ} \mathrm{C}$ is thought to limit volatilization of moderately volatile trace elements such as As, and retain all but the most volatile elements (Hg and Se; Palmer, 1997). In USGS determinations of arsenic by ICP-MS, results are corrected for a polyatomic interference at mass 75 resulting from the presence of $\mathrm{Cl}^{35}$ in combination with $\mathrm{Ar}^{40}$. In the correction, the polyatomic species $\left(\mathrm{Cl}^{37}+\mathrm{Ar}^{40}\right)$ at mass 77 is used to give the contribution of $\left(\mathrm{Cl}^{35}+\mathrm{Ar}^{40}\right)$ at mass 75. This correction is adjusted for an interference at mass 77 with any remaining selenium. The contribution of $\mathrm{Se}^{77}$ is determined by measuring $\mathrm{Se}^{82}$, which has few interferences, and can therefore be used to obtain the proportion of any isotope of Se present. A promising new method for As and Se ICP-MS determination in coal not used in the present study utilizes microwave digestion in a closed vessel to minimize element volatility together with a collision/reaction cell to minimize spectral interferences by Ar-based polyatomic ions (Li et al., 2014).

Pyrite grains identified in the separates were checked for compositional variation by backscattered electron imaging and wavelength-dispersive elemental mapping, using a JEOL JXA 8900R electron microprobe at the USGS in Reston. These grains were then analyzed by laser ablation ICP-MS (LA ICP-MS) spot analysis at the USGS in Denver. Pyrites were ablated using spot sizes of $25 \mu \mathrm{m}$ or $20 \mu \mathrm{m}$ as necessary, with calibration using USGS synthetic sulfide 
standard MASS-1, which is homogeneous at a minimum of $20 \mu \mathrm{m}$ (Wilson et al., 2002). In most cases, detection limits are lower for results determined at $25 \mu \mathrm{m}$ than at $20 \mu \mathrm{m}$ because a larger volume of material is ablated.

\section{Results}

\subsection{Bulk analysis}

The separation process concentrates pyrite in the high density fractions, either as float or sink

(Fig. 1, 2; Table 2). Bulk Hg contents of the separates are well correlated with pyritic sulfur $\left(\mathrm{R}^{2}=\right.$ 0.81 , and with ash yield $\left(R^{2}=0.90 ;\right.$ Fig. 1). Arsenic also increases with ash yield (Fig. 2). A similar pronounced increase with ash yield is shown by $\mathrm{Ni}, \mathrm{Se}, \mathrm{Mo}, \mathrm{Tl}$ and $\mathrm{Pb}$, consistent with the occurrence of these elements in pyrite (following section), whereas $\mathrm{Mn}$ and $\mathrm{Cr}$ are more broadly enriched with ash yield, suggesting a mixed association, possibly including substitution in illite-smectite clay minerals, and possibly, an organic association. Cobalt shows the greatest enrichment in both the lowest and highest density fractions, suggesting it has both an organic and a pyritic association (Fig. 2). Bulk trace element variation with ash yield does not result in smooth curves because: 1 ) The increase in pyritic sulfur with density is not uniform (sample 2.0F has less pyritic sulfur than sample $1.9 \mathrm{~F}$ or $2.0 \mathrm{~S}$ ); and 2) for mercury, results may be impacted by a nugget effect (Kolker et al., 2014). Bulk halogen contents of South African coals are low (Cairncross et al., 1990; Kolker et al., 2014), but in the separates, $\mathrm{Cl}$ and $\mathrm{F}$ are more concentrated in the low-ash fractions (Table 2), consistent with binding of halogens to organic portions of the coal (Huggins and Huffman, 1995). 
Simple combinations of results for the density separates allow prediction of coal quality and element partitioning in commercial coal products used in South Africa. These include: 1) export; 2) de-stoned; 3) middling; 4) run-of-mine; 5) middling plus discard; and 6) stone (discard), listed in order of increasing ash yield predicted from the density fractions (Table 3). Mercury concentrations calculated for these products range from $0.06 \mathrm{ppm}$ for export coal to $0.47 \mathrm{ppm}$ for stone. These results are illustrative of the difference in quality of coals prepared for export and those used for domestic power generation. In practice, the middlings fraction may have a higher ash yield than run-of-mine coal (Wagner and Hlatshwayo, 2005), but the standard for export coal is to contain no more than $16 \%$ ash (Snyman and Botha, 1993; whole coal basis), as the density separates predict. Past USGS analysis of export quality Highveld coals confirms Hg concentrations of about 0.05 ppm (Tewalt et al., 2010). These export coals have $\mathrm{Hg}$ concentrations that are roughly half that of the global average $(0.10 \mathrm{ppm}$; Ketris and Yudovich, 2009) and that of the mean for coals delivered to U.S. power stations (0.11-0.12 ppm; Kolker and Quick, 2015). Feed coals burned in South African power stations typically have mercury contents that are 3-5 times higher than those of export coals, with corresponding ash yields in the $30 \%$ range (Gericke et al., 2007; Kolker et al., 2014). Arsenic and Se contents of the density separates show corresponding variation with mercury, but whole coal values for As and Se predicted by averaging all eight separates are low in comparison to world averages for bituminous coals (Ketris and Yudovich, 2009; Table 3).

4.2 Microanalysis

Three distinct pyrite forms were found in the Highveld (\#4) coal. These include large complex composite grains that appear to have a multistage history based on an observed sequence of 
overgrowths on framboid clusters (Fig. 3), and a smaller number of individual framboids and cleat-filling pyrites, the earliest and latest generations, respectively, based on the sequence of overgrowths and on crosscutting relations. For LA ICP-MS analysis, a total of 263 points on 21 pyrite grains was determined, including 163 ablations using a $20 \mu \mathrm{m}$ spot and 100 determinations at $25 \mu \mathrm{m}$ (Fig. 4). Cleat pyrite and individual framboids combined accounted for only about 7\% of the LA ICP-MS analyses. This was not sufficient to determine if these forms are compositionally distinct from the large composite grains, although composite pyrites in coal commonly include coalesced agglomerations of framboids (Kolker, 2012).

Results for $\mathrm{Hg}$ in pyrite show a heterogeneous spatial distribution with typical values ranging from the detection limits to about $3 \mathrm{ppm}$. The large difference in mean values obtained in $20 \mu \mathrm{m}$ ablations $(2.43 \mathrm{ppm})$ versus the $25 \mu \mathrm{m}$ results $(1.14 \mathrm{ppm})$ reflects sample heterogeneity and inclusion of several $10+\mathrm{ppm} \mathrm{Hg}$ determinations in the mean determined for analyses at $20 \mu \mathrm{m}$ (Table 4). These heterogeneities also contribute to variation in bulk analysis of $\mathrm{Hg}$ due to a nugget effect in which overall distribution is strongly controlled by localized $\mathrm{Hg}$ enriched domains. Results for arsenic also show a heterogeneous distribution. On the grain scale, enrichment of $\mathrm{Hg}$ and As is both coupled and de-coupled (Fig. 4).

In addition to $\mathrm{Hg}$ and $\mathrm{As},-, \mathrm{Mn}, \mathrm{Co}, \mathrm{Ni}, \mathrm{Cu}, \mathrm{Zn}, \mathrm{Se}, \mathrm{Mo}, \mathrm{Tl}, \mathrm{Pb}$, and $\mathrm{Bi}$, were detected in pyrite by LA ICP-MS (Table 4). Detection limits for each element vary by spot size, as do the proportion of analyses that exceeded the detection limit. Where at least $50 \%$ of the analyses for a given element exceeded the detection limit, mean concentrations in pyrite were calculated by substituting $66 \%$ of the detection limit for non-detects (Martín-Fernández et al., 2003, and references therein). These mean concentrations were used to determine element 
enrichments in pyrite relative to whole coal values which were estimated by averaging results for all eight separates, as shown in Table 3 for run-of-mine coal. Five elements, As, Mo, $\mathrm{Hg}, \mathrm{TI}$, and $\mathrm{Pb}$, each had more than $50 \%$ non-censored determinations for both the 25 - and $20 \mu \mathrm{m}$ spot sizes. These give enrichment factors (degrees of enrichment in pyrite relative to the whole coal) of 20.3 to $33.2(\mathrm{As}), 13.5$ to 17.4 (Mo), 3.9 to $8.4(\mathrm{Hg}), 29.5$ to $36.4(\mathrm{Tl})$, and 2.1 to $4.4(\mathrm{~Pb})$, for 25 - and $20 \mu \mathrm{m}$ determinations, respectively (Table 4). The range in values for a given element is a function of sample heterogeneity on a grain scale (Fig. 4) and differences in detection limits for each ablation diameter. Results for each element are consistent with variation seen in the bulk samples with progressive increases corresponding to an increase in the proportion of pyrite contained (Table 2; Fig. 1, 2).

\section{Discussion}

Density separation is effective in showing trace element and mineralogical variation within separates having a range of ash yields (Spears et al., 1999; Senior et al., 2000; Querol et al., 2001; Huggins et al., 2009). For South African coals, this approach has been applied by Bergh et al. (2011) for the Witbank no. 4 coal, and by Wagner and Tlotleng (2012), for samples of Waterburg coal. Laser ablation ICP-MS can selectively determine trace element affinities in coal and coal constituents at concentrations below those measureable by electron-beam instruments (Querol and Chenery, 1995; Booth et al., 1999; Spears et al., 2007). Despite having advantages in spatial resolution and detection limits, previous studies applying LA ICP-MS for analysis of coal constituents are limited, especially for $\mathrm{Hg}$. Diehl et al. $(2004,2012)$ determined $\mathrm{Hg}$ contents much exceeding those in the host coals, in pyrite occurring within coals of the southern and central Appalachian Basin, USA. Similarly, reconnaissance determinations by 
proton-induced X-Ray emission (PIXE) for selected U.S. coals show Hg enrichment in pyrite (Hickmott, 1993; Hower et al., 2008). The association of trace elements with pyrite is also shown by selective leaching, in which iron disulfides are soluble in nitric acid (Palmer et al., 1998; Spears, 2013) or nitric-dominated leachates (Zheng et al., 2008), and Hg typically occurs within the pyritic fraction (Palmer et al., 1998; Zheng et al., 2007). These direct and indirect methods confirm a common association of $\mathrm{Hg}$ with iron disulfides, especially for Carboniferous coals of the northern hemisphere (e.g. Finkelman, 1995; Yudovich and Ketris, 2005; Kolker, et al., 2006; Spears and Tewalt, 2009; Kolker, 2012, Kolker and Quick, 2015).

More complete information on modes of occurrence of trace elements in Gondwanan coals is emerging. Riley et al. (2012) found that mercury is predominantly associated with pyrite in low sulfur Permian and Triassic coals of Australia, whereas results for As are more variable. Oliveira et al. (2013) found that both $\mathrm{As}$ and $\mathrm{Pb}$ are reduced in beneficiation of Permian coals from southern Brazil, and attribute this reduction to pyrite removal. The pyritic association in these coals likely extends to $\mathrm{Hg}$, which was not determined. Similarly, in the present study, a pyritic association was found for $\mathrm{As}$ and $\mathrm{Hg}$ (and to a lesser extent, $\mathrm{Pb}$ ), by direct determination using LA ICP-MS. Whereas we did not analyze organic portions of the Highveld \#4 density separates by LA ICP-MS, sample $1.4 \mathrm{~F}$, having a pyritic sulfur content of only $0.02 \%$, has $20 \%$ of the mercury estimated for the whole coal. This may present a limit to the extent that $\mathrm{Hg}$ reduction is possible, as organic-hosted mercury likely constitutes a small portion of total mercury dominated by the pyritic form.

\section{Summary and Conclusions}


Combined results from bulk analysis of density separates and LA-ICP-MS of pyrite and for a Highveld (\#4) coal indicate that reduction of $\mathrm{Hg}$ and As by coal washing should be straightforward, as both elements reside almost exclusively in pyrite. Other elements of environmental concern, such as $\mathrm{Mn}, \mathrm{Co}, \mathrm{Ni}, \mathrm{Se}, \mathrm{Mo}, \mathrm{Tl}$ and $\mathrm{Pb}$, are detectable in pyrite in $\mathrm{LA}$ ICP-MS spot analyses and these should also be reduced by coal washing, although the extents of reduction vary, especially for elements with multiple associations such as $\mathrm{Mn}$ and Co. The low overall As content in Highveld coals is explained by relatively low concentrations of As in pyrite, approximately $50 \mathrm{ppm}$ on average. While the $\mathrm{Hg}$ and $\mathrm{As}$ contents in pyrite are quite variable on a micrometer scale, LA-ICP-MS confirms these pyritic associations and enrichment relative to the whole coal. Reduction of $\mathrm{Hg}$ input to the boiler can be achieved by discarding the pyrite-enriched stone fraction, as is employed by Eskom, and by retention of as much of the low-ash fraction as is practical.

\section{Acknowledgements}

This work was performed under an agreement between the United Nations Environment Programme, DTIE Chemicals Branch, Geneva, Switzerland, and the U.S. Geological Survey, Reston, Virginia, USA, with funding from the European Union. USGS participation in the study was supported by the USGS Energy Resources Program. We thank Gunnar Futsaeter, UNEP Project Manager and Kristy Langerman of Eskom for their interest and cooperation. Initial reviews for the USGS by Paul Hackley and Clinton Scott helped improve the manuscript, as did the comments of Editor Shifeng Dai and two Journal reviewers. A. Rae Ann Orkild-Norton assisted in acquisition of LA ICP-MS data. Any use of trade, firm, or product names is for 
descriptive purposes only and does not imply endorsement by the U.S. Government. Neither the United States Government nor any agency thereof, nor any of its employees, make any warranty, expressed or implied, or assume any legal liability or responsibility for the accuracy, completeness, or usefulness of any information, apparatus, product, or process disclosed in this report, or represent that its use would not infringe privately owned rights.

\section{References}

AMAP/UNEP, 2013, Technical Background Report for the Global Mercury Assessment 2013: published by Arctic Monitoring and Assessment Programme, Oslo, Norway and UNEP Chemicals Branch, Geneva, Switzerland, $263 \mathrm{p}$.

American Society for Testing and Materials International (ASTM), 2014, Annual book of ASTM standards, section five, petroleum products, lubricants, and fossil fuels, Gaseous fuels; coal and coke: West Conshohocken, Pennsylvania, American Society for Testing and Materials International, http://www.astm.org/.

Bergh, J.P., Falcon, R.M.S., and Falcon, L.M., 2011, Trace element concentration reduction by beneficiation of Witbank Coalfield no. 4 Seam. Fuel Processing Technology 92, 812-816.

Booth, C.A., Spears, D.A., Krause, P., and Cox, A.G., 1999, The determination of low level trace elements in coals by laser ablation-inductively coupled plasma-mass spectrometry. Fuel 78 1665-1670.

Bragg, L. J., Oman, J. K., Tewalt, S. J., Oman, C. L., Rega, N. H., Washington, P. M., and Finkelman, R. B., 1998, U. S. Geological Survey Coal Quality (COALQUAL) Database: Version 2.0: U.S. Geological Survey Open File Report 97-134, CD-ROM.

Cairncross, B., Hart, R.J., and Willis, J.P., 1990, Geochemistry and sedimentology of coal seams from the Permian Witbank Coalfield, South Africa; a means of identification. International Journal of Coal Geology, 16 309-325.

Dabrowski, J.M., Ashton, P.J., Murray, K., Leaner, J.J., and Mason, R.P., 2008, Anthropogenic mercury emissions in South Africa: Coal combustion in power plants. Atmospheric Environment 426620 6626. 
Dai, S., Ren, D., Chou, C.-L., Finkelman, R.B., Seredin, V.V., and Zhou, Y., 2012, Geochemistry of trace elements in Chinese coals: A review of abundances, genetic types, impacts on human health, and industrial utilization. International Journal of Coal Geology 94 3-21.

Diehl, S.F., Goldhaber, M.B., and Hatch, J.R., 2004, Modes of occurrence of mercury and other trace elements in coals from the warrior field, Black Warrior Basin, Northwestern Alabama. International Journal of Coal Geology 59 193-208.

Diehl, S.F., Goldhaber, M.B., Koenig, A.E., Lowers, H.A., and Ruppert, L.F., 2012, Distribution of arsenic, selenium, and other trace elements in high pyrite Appalachian coals: Evidence for multiple episodes of pyrite formation. International Journal of Coal Geology 94 238-249.

Eskom Holdings SOC Ltd. (Eskom), 2014, Eskom Integrated Report, 2014, http://integratedreport.eskom.co.za/pdf/full-integrated.pdf, accessed Dec. 2, 2014.

Falcon, R.M.S., 1986, Classification of coals in southern Africa: in, Annhaesser, C.R., and Maske, S., eds., Mineral deposits of southern Africa, vol. II, Geol. Society of Southern Africa, p. 1899-1921.

Finkelman, R.B., 1995. Modes of occurrence of environmentally-sensitive trace elements in coal. In: Swaine, D.J., Goodarzi, F. (eds), Environmental Aspects of Trace Elements in Coal, Kluwer Academic Publishers, p. 24-50.

Gericke, G., Surender, D., and Delport, W., 2007, Executive summary of mercury research and trace element behavior, Eskom Report C096501, Eskom, Johannesburg (results given in Scott, 2011).

Hancox, P. J., and Götz, A. E., 2014, South Africa's coalfields - A 2014 perspective. International Journal of Coal Geology 132 170-254.

Hickmott, D.D., 1993. PIXE microanalysis of Fe-sulfides: comparison of eastern and western U.S. coals. In: Michaelian, K.H. (ed), Proceedings, Seventh International Conference on Coal Science, Devon, Alberta, Canada, v. 1, p. 648-651.

Hower, J.C., Campbell, J.L., Teesdale, W.J., Nejedly, Zdenek, Robertson, J.D., 2008. Scanning proton microprobe analysis of mercury and other trace elements in Fe-sulfides from a Kentucky coal. International Journal of Coal Geology 75 88-92.

Huggins, F.E., and Huffman, G.P., 1995, Chlorine in coal: An XAFS spectroscopic investigation. Fuel 74 556-569.

Huggins, F.E., Seidu, L.B.A., Shah, N., Huffman, G.P., Honaker, R.Q., Kyger, J.R., Higgins, B.L., Robertson, J.D., Pal, S., Seehra, M.S., 2009. Elemental modes of occurrence in an Illinois \#6 coal and fractions prepared by physical separation techniques at a coal preparation plant. International Journal of Coal Geology 78 65-76. 
Jeffrey, L.S., 2005, Characterization of the coal resources of South Africa: The Journal of the South African Institute of Mining and Metallurgy, February, 2005, p. 95-102.

Ketris, M.P., and Yudovich, Y.E., 2009, Estimations of Clarkes for Carbonaceous biolithes: World averages for trace element contents in black shales and coals. International Journal of Coal Geology 78 135148.

Kolker, A., 2012, Minor element distribution in iron-disulfides in coal: A geochemical review. International Journal of Coal Geology 94 32-43.

Kolker, A., and Quick, J. C., 2015, Mercury and halogens in coal, in, Granite, E.J., Pennline, H.W., and Senior, C., eds., Mercury control for coal-derived gas streams, Weinheim, Wiley-VCH, p. 13-44.

Kolker ${ }_{2}$ A., Senior, C., and Quick, J. C., 2006, Mercury in coal and the impact of coal quality on mercury emissions from combustion systems. Applied Geochemistry 21 1821-1836

Kolker, A., Senior, C., and van Alphen, C., 2014, Collaborative studies for mercury characterization in coal and coal combustion products, Republic of South Africa: U.S. Geological Survey Open File Report 2014-1153, http://pubs.usgs.gov/of/2014/1153/, revised, 2016.

Leaner, J., Dabrowski, J., Mason, R., Resane, T., Richardson, M., Ginster, M., Euripides, R., and Masekoameng, E., 2009, Mercury emissions from point sources in South Africa, in Pirrone, N., and Mason, R., (eds.), Mercury fate and transport in the global atmosphere, Springer Verlag, p. 113-130.

Li, X., Dai, S. Zhang, W., Li, T., Zheng, X, and Chen, W., 2014, Determination of As and Se in coal and coal combustion products using closed vessel microwave digestion and collision/reaction cell technology (CCT) of inductively coupled plasma mass spectrometry (ICP-MS): International Journal of Coal Geology 124 1-4.

Martín-Fernández, J.A., Barceló-Vidal, C., and Pawlowsky-Glahn, V., 2003, Dealing with zeros and missing values in compositional data sets using nonparametric imputation. Mathematical Geology 35, 253278.

Masekoameng, E., Leaner, J., and Dabrowski, J., 2010, Trends in anthropogenic mercury emissions estimated for South Africa during 2000-2006. Atmospheric Environment 44 3007-3014.

Oliveira, M.L.S., Ward, C.R., Sampaio, C.H., Querol, X., Cutrunea, C.M.N.L., Taffarel, S.R., and Silva, L.F.O., 2013, Partitioning of mineralogical and inorganic geochemical components of coals from Santa Catarina, Brazil, by industrial beneficiation processes. International Journal of Coal Geology 116-117 75-92. 
Pacyna, E.G., Pacyna, J.M., Steenhuisen, F., and Wilson, S., 2006, Global anthropogenic mercury emission inventory for 2000. Atmospheric Environment 40 4048-4063.

Palmer, C.A., ed., 1997, The chemical analysis of Argonne Premium Coal samples, U.S. Geological Survey Bulletin 2144, $106 \mathrm{p}$.

Palmer, C.A., Mroczkowski, S.J., Finkelman, R.B., Crowley, S.S., 1998. The use of sequential leaching to quantify the modes of occurrence of elements in coals. Proceedings, Fifteenth Annual International Pittsburgh Coal conference, 28 p., CD-ROM.

Pretorius, C.C., Boshoff, H.P., and Pinheiro, H.J., 2002, Analysis of coal product samples of South African Collieries, 2001-2002: Bulletin 114, Energy Branch, South African Department of Minerals and Energy, Coal and Mineral Technologies (Pty) Ltd, South African Bureau of Standards, Pretoria, 25 p.

Querol, X. Chenery, S., 1995. Determination of trace element affinities in coal by laser ablation microprobe-inductively coupled plasma mass spectrometry. In: Whateley, M.K.G.,Spears, D.A. (eds), European Coal Geology. Geological Society Special Publication 82 147-155.

Querol, X., Klika, Z., Weiss, Z., Finkelman, R. B., Alastuey, A., Juan, Lopez-Soler, A., Plana, F., Kolker, A., and Chenery, S. R. N., 2001, Determination of element affinities by density fractionation of bulk coal samples. Fuel 80 83-96.

Riley, K.W., French, D.H., Farrell, O.P., Wood, R.A., and Huggins, F.E., 2012, Modes of occurrence of trace and minor elements in some Australian coals. International Journal of Coal Geology 94 214-224.

Scott, G., 2011, Reducing mercury emissions from coal combustion in the energy sector in South Africa: Final Project Report, UNEP Global Mercury Partnership, Mercury in Coal Project Area, 18 p., http://www.unep.org/chemicalsandwaste/Portals/9/Mercury/Documents/coal/Report\%20FINAL31 \%20jan\%202012.pdf, accessed Nov. 20, 2014.

Senior, C. L., Zeng, T.,Che, J., Ames, M .R., Sarofim, A. F., Olmez, I., Huggins, F. E., Shah, N., Huffman, G. P., Kolker, A., Mroczkowski, S., Palmer, C. A., and Finkelman, R. B., 2000, Distribution of trace elements in selected pulverized coals as a function of particle size and density. Fuel Processing Technology 63 215-241.

Spears, D.A., 2013, The determination of trace element distributions in coals using sequential chemical leaching- A new approach to an old method. Fuel 114 31-37.

Spears, D.A., and Tewalt, S.J., 2009, The geochemistry of environmentally important trace elements in UK coals, with special reference to the Parkgate coal in the Yorkshire-Nottinghamshire Coalfield, UK. International Journal of Coal Geology 80 157-166. 
Spears, D.A., Manzanares-Papayanopoulos, L.I., and Booth, C.A., 1999, The distribution and origin of trace elements in UK coal; the importance of pyrite. Fuel 78 1671-1677.

Spears, D.A., Borrego, A.G., Cox, A., and Martinez-Tarazona, R.M., 2007, Use of laser ablation ICP-MS to determine trace element distributions in coals, with special reference to $\mathrm{V}, \mathrm{Ge}$, and Al. International Journal of Coal Geology 72 165-176.

Snyman, C.P., and Botha, W. J., 1993, Coal in South Africa: Journal of African Earth Sciences, 16, 171-180.

Tewalt, S.J., Belkin, H.E., SanFilipo, J.R., Merrill, M.D., Palmer, C.A., Warwick, P.D., Karlsen, A.W., Finkelman, R.B., and Park, A.J., 2010, Chemical analyses in the world coal quality inventory, version 1: U.S. Geological Survey Open File Report 2010-1196, http://pubs.usgs.gov/of/2010/1196/, 4 p. and data files, accessed Oct. 22, 2014.

U.S. Environmental Protection Agency (EPA), 2007, Method 7473, Mercury in solids and solutions by thermal decomposition, amalgamation, and atomic absorption spectrophotometry, http://www.epa.gov/wastes/hazard/testmethods/sw846/pdfs/7473.pdf, 17 p., accessed Oct. 27, 2014

U.S. Environmental Protection Agency (EPA), 2011, Mercury and Air Toxics Standards (MATS): http://www.epa.gov/mats/pdfs/20111216MATSfinal.pdf, 1117 p., accessed Oct. 24, 2014.

Wagner, N.J., and Hlatshwayo, B., 2005, The occurrence of potentially hazardous trace elements in five Highveld coals, South Africa. International Journal of Coal Geology 63 228-246.

Wagner, N.J., and Tlotleng, M.T., 2012, Distribution of selected trace elements in density fractionated Waterberg coals from South Africa: International Journal of Coal Geology 94 225-237.

Wilson, S.A., Ridley, W.I., and Koenig, A.E., 2002, Development of sulfide calibration standards for the laser ablation inductively-coupled plasma mass spectrometry technique: Journal of Analytical Atomic Spectrometry 17 406-409.

World Coal Association, 2014, Coal Facts 2013, http://www.worldcoal.org/resources/coal-statistics/, 3 p., accessed Sept. 8, 2014.

Yudovich, Ya. E., and Ketris, M.P., 2005, Mercury in coal: a review Part 1. Geochemistry. International Journal of Coal Geology 62 107-134.

Zheng, L., Liu, G., Qi, C., Zhang, Y., and Wong, M., 2008, The use of sequential extraction to determine the distribution and modes of occurrence of mercury in Permian Huaibei coal, Anhui Province, China. International Journal of Coal Geology 73 139-155. 
Table 1. Characteristics of density separates (in percent on an as-received basis) ${ }^{1}$

\begin{tabular}{|c|c|c|c|c|c|c|c|}
\hline $\begin{array}{c}\text { Sample } \\
\text { (Density } \\
\text { Cut) }\end{array}$ & Ash $^{\mathbf{2}}$ & Moisture $^{\mathbf{2}}$ & $\begin{array}{c}\text { Heating } \\
\text { value } \\
\text { (MJ/kg) }\end{array}$ & Organic S & Pyritic S & Sulfate S & Yield (\%) \\
\hline $\mathbf{1 . 4 \mathbf { F } ^ { \mathbf { 3 } }}$ & 10.91 & 5.16 & 26.20 & 0.67 & 0.02 & 0.01 & 3.05 \\
\hline $\mathbf{1 . 5} \mathbf{~ F}$ & 16.75 & 5.26 & 23.77 & 0.60 & 0.06 & 0.00 & 8.29 \\
\hline $\mathbf{1 . 6} \mathbf{F}$ & 22.23 & 5.17 & 21.65 & 0.56 & 0.10 & 0.01 & 22.52 \\
\hline $\mathbf{1 . 7} \mathbf{~ F}$ & 27.18 & 5.03 & 19.91 & 0.52 & 0.18 & 0.00 & 27.28 \\
\hline $\mathbf{1 . 8} \mathbf{F}$ & 32.26 & 4.81 & 18.32 & 0.53 & 0.42 & 0.02 & 5.55 \\
\hline $\mathbf{1 . 9} \mathbf{F}$ & 42.88 & 4.13 & 14.55 & 0.37 & 0.75 & 0.03 & 3.65 \\
\hline $\mathbf{2 . 0} \mathbf{F}$ & 49.75 & 3.97 & 12.19 & 0.34 & 0.50 & 0.01 & 3.65 \\
\hline $\mathbf{2 . 0} \mathbf{S}$ & 68.29 & 2.35 & 6.39 & 0.24 & 1.00 & 0.01 & 26.01 \\
\hline
\end{tabular}

${ }^{1}$ Results determined by Geochemical Testing, Inc., Somerset, PA, USA, USGS contract laboratory.

${ }^{2}$ Values used to express trace element results for ashed coal sample on a whole-coal dry basis (Table 2).

${ }^{3} \mathrm{~F}=$ Float; $\mathrm{S}=$ Sink 
Table 2. $\mathrm{Hg}$ and trace elements in density separates (in ppm on a whole-coal dry basis) ${ }^{1}$.

\begin{tabular}{|c|c|c|c|c|c|c|c|c|c|c|c|c|c|c|c|}
\hline Sample & $B e^{2}$ & $F^{3}$ & $\mathrm{Cl}$ & $\mathrm{Cr}^{4}$ & Mn & Co & $\mathbf{N i}$ & $\mathrm{Zn}$ & As & Se & Mo & $\mathrm{Sb}$ & $\mathrm{Hg}^{5}$ & TI & $\mathbf{P b}$ \\
\hline $1.4 \mathrm{~F}$ & 0.8 & 311 & 540 & 31 & 29 & 9.3 & 15 & 3.0 & 0.5 & 0.5 & 1.7 & 0.5 & 0.06 & $<0.05$ & 2.6 \\
\hline $1.5 \mathrm{~F}$ & 1.4 & 239 & 1084 & 39 & 43 & 5.2 & 16 & 4.7 & 0.9 & 1.0 & 1.5 & 0.6 & 0.06 & 0.06 & 7.1 \\
\hline $1.6 \mathrm{~F}$ & 1.6 & 171 & 1037 & 34 & 62 & 2.8 & 15 & 4.3 & 1.0 & 1.0 & 1.6 & 0.6 & 0.10 & 0.07 & 6.8 \\
\hline $1.7 \mathrm{~F}$ & 1.7 & 140 & 770 & 33 & 74 & 2.0 & 14 & 4.4 & 1.2 & 1.0 & 2.1 & 0.4 & 0.25 & 0.11 & 7.5 \\
\hline $1.8 \mathrm{~F}$ & 2.6 & 154 & 807 & 59 & 67 & 2.5 & 18 & 4.9 & 1.7 & 1.2 & 3.2 & 0.3 & 0.32 & 0.22 & 10 \\
\hline $2.0 \mathrm{~F}$ & 2.9 & 120 & 536 & 65 & 55 & 2.4 & 24 & $15^{6}$ & 3.2 & 1.5 & 2.9 & 0.4 & 0.45 & 0.28 & 12 \\
\hline $2.0 \mathrm{~S}$ & 1.8 & 140 & 428 & 70 & 51 & 8.7 & 41 & 21 & 4.4 & 1.3 & $3.5^{6}$ & 0.5 & 0.47 & 0.51 & 11 \\
\hline
\end{tabular}

${ }^{1}$ Emissions proposed for regulation under the former U.S. EPA MATS standards [18] shown in boldface.

${ }^{2}$ Elements determined using ICP-MS by Actlabs, Ancaster, Ontario, Canada: Be, Mn, Co, Ni, Zn, Se, Mo, Cd, TI, Pb.

${ }^{3}$ Elements determined using ion-selective electrode by Geochemical Testing, Inc., Somerset, PA, USA: $\mathrm{F}, \mathrm{Cl}$.

${ }^{4}$ Elements determined using ICP-MS by USGS in re-analysis of values originally reported in Kolker et al., $2014: \mathrm{Cr}$, As, $\mathrm{Sb}$.

${ }^{5} \mathrm{Hg}$ values are means of multiple USGS analyses (Appendix 1 in Kolker et al., 2014).

${ }^{6}$ USGS value used for Mo in 2.0S; USGS and Actlabs values are averaged for $\mathrm{Zn}$ in $2.0 \mathrm{~F}$. 
Table 3. Ash yield, mercury, arsenic, and selenium contents of coal products predicted from Highveld (\#4) density separates, expressed on a dry basis.

\begin{tabular}{|l|c|c|c|c|c|l|}
\hline Product & $\begin{array}{c}\text { Samples } \\
\text { (averaged) }\end{array}$ & $\begin{array}{c}\text { Ash } \\
\text { (wt. } \\
\text { percent) }\end{array}$ & $\begin{array}{c}\mathbf{H g} \\
\text { (ppm) }\end{array}$ & $\begin{array}{c}\text { As } \\
\text { (ppm) }\end{array}$ & $\begin{array}{c}\text { Se } \\
\text { (ppm) }\end{array}$ & $\begin{array}{l}\text { Approximate } \\
\text { cut point }\end{array}$ \\
\hline Export & $\mathbf{1 . 4 F}$ & 11.5 & 0.06 & 0.5 & 0.5 & Cut at 1.4 \\
\hline De-stoned & 1.4F to 1.9F & 26.6 & 0.24 & 1.4 & 1.0 & Cut at 1.9 \\
\hline & & & & & & \\
\hline Middling & 1.5F to 1.9F & 29.7 & 0.27 & 1.5 & 1.1 & 1.4 to 1.9 \\
\hline & & & & & & \\
\hline Run-of-mine & $\mathbf{1 . 4 F}$ to 2.0S & 35.2 & 0.29 & 2.0 & 1.1 & No washing \\
\hline & & & & & & \\
\hline $\begin{array}{l}\text { Middling + } \\
\text { discard }\end{array}$ & $\mathbf{1 . 5 F}$ to 2.0S & 38.6 & 0.32 & 2.2 & 1.2 & $>1.4$ \\
\hline & & & & & & \\
\hline Stone (discard) & $\mathbf{2 . 0 F , ~ 2 . 0 S}$ & 60.9 & 0.46 & 3.8 & 1.4 & $>2.0$ \\
\hline
\end{tabular}


Table 4. Laser ablation ICP-MS analysis data showing detection limits in ppm, calculated mean values for As, $\mathrm{Mo}, \mathrm{Hg}, \mathrm{Tl}$, and $\mathrm{Pb},(>50 \%$ detected) and element enrichment factors in pyrite relative to calculated whole coal (dry basis).

\begin{tabular}{|c|c|c|c|c|c|c|c|c|c|}
\hline & Mn & Co & $\mathrm{Ni}$ & As & $\mathrm{Se}$ & Mo & $\mathrm{Hg}$ & $\mathrm{TI}$ & $\mathrm{Pb}$ \\
\hline & \multicolumn{9}{|c|}{20 Micrometer Spot $(n=163)$} \\
\hline Detection limit (ppm) & 25.2 & 11.6 & 365 & 40.1 & 20.2 & 15.0 & 0.74 & 1.13 & 2.39 \\
\hline Percent detects & $40 \%$ & $42 \%$ & $21 \%$ & $56 \%$ & $29 \%$ & $69 \%$ & $85 \%$ & $72 \%$ & $63 \%$ \\
\hline Mean (ppm) & --- & --- & --- & $66.4^{1}$ & --- & 45.3 & $2.43^{1}$ & 6.92 & $36.9^{1}$ \\
\hline Calculated whole coal $^{2}$ & & & & 2.0 & & 2.6 & 0.29 & $0.19^{3}$ & 8.4 \\
\hline \multirow[t]{2}{*}{ Enrichment factor } & & & & 33.2 & & 17.4 & 8.4 & 36.4 & 4.4 \\
\hline & \multicolumn{9}{|c|}{25 Micrometer Spot $(n=100)$} \\
\hline Detection limit (ppm) & 16.4 & 8.8 & 37.1 & 15.3 & $163^{4}$ & 11.2 & 0.49 & 0.78 & 1.93 \\
\hline Percent detects & $47 \%$ & $28 \%$ & $23 \%$ & $72 \%$ & $9 \%$ & $75 \%$ & $80 \%$ & $68 \%$ & $73 \%$ \\
\hline Mean (ppm) & --- & --- & -- & 40.5 & --- & 35.1 & 1.14 & 5.60 & 17.8 \\
\hline Calculated whole coal ${ }^{2}$ & & & & 2.0 & & 2.6 & 0.29 & 0.19 & 8.4 \\
\hline Enrichment factor & & & & 20.3 & & 13.5 & 3.9 & 29.5 & 2.1 \\
\hline
\end{tabular}

${ }^{1}$ Excludes one analysis with $983 \mathrm{ppm} \mathrm{As}, 64.5 \mathrm{ppm} \mathrm{Hg}$, and 6,319 ppm Pb. Non-detects counted as $66 \%$ of the detection limit (Martín-Fernández et al., 2003).

${ }^{2}$ Whole coal value estimated by averaging all eight density separates.

${ }^{3}$ Whole coal value estimated for $\mathrm{Tl}$ includes one non-detect counted as $2 / 3$ of the detection limit.

${ }^{4}$ Detection limit for Se varies with instrument conditions and was better for $20 \mu \mathrm{m}$ spot than for $25 \mu \mathrm{m}$.

Other elements detected: $\mathrm{Cu}, \mathrm{Zn}, \mathrm{Bi}$ 

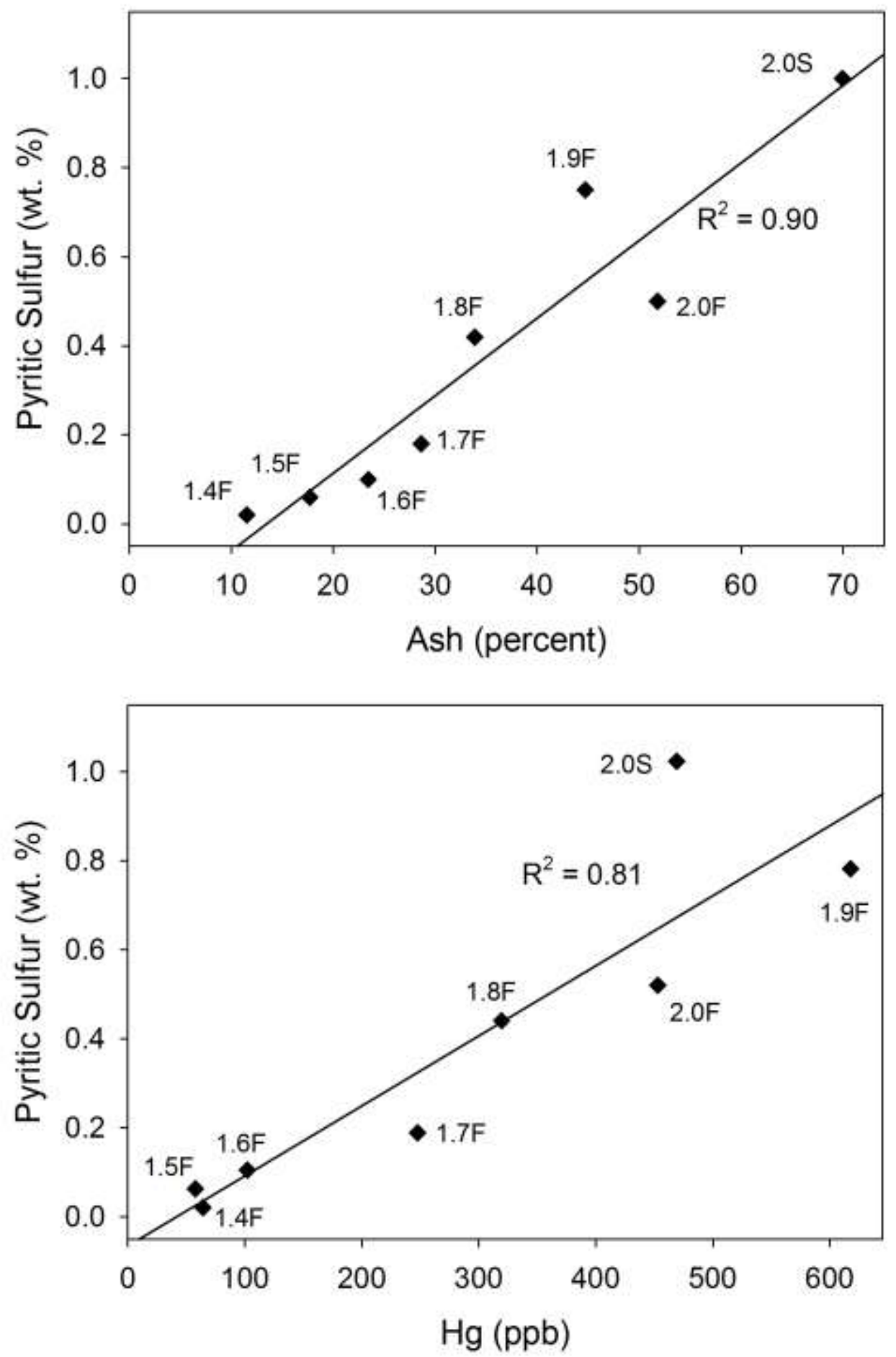

Figure 1. Plots of ash yield (upper) and mercury (lower plot) vs. pyritic sulfur for Highveld (\#4) density separates, showing concentration of pyrite and $\mathrm{Hg}$ in the high-density cuts (results on a whole coal dry basis). Sample numbers refer to densities of heavy media, ranging from 1.4 to $2.0 \mathrm{~g} / \mathrm{cm}^{3}$, and whether the separate represents the float $(\mathrm{F})$ or $\operatorname{sink}(\mathrm{S})$ fraction. 

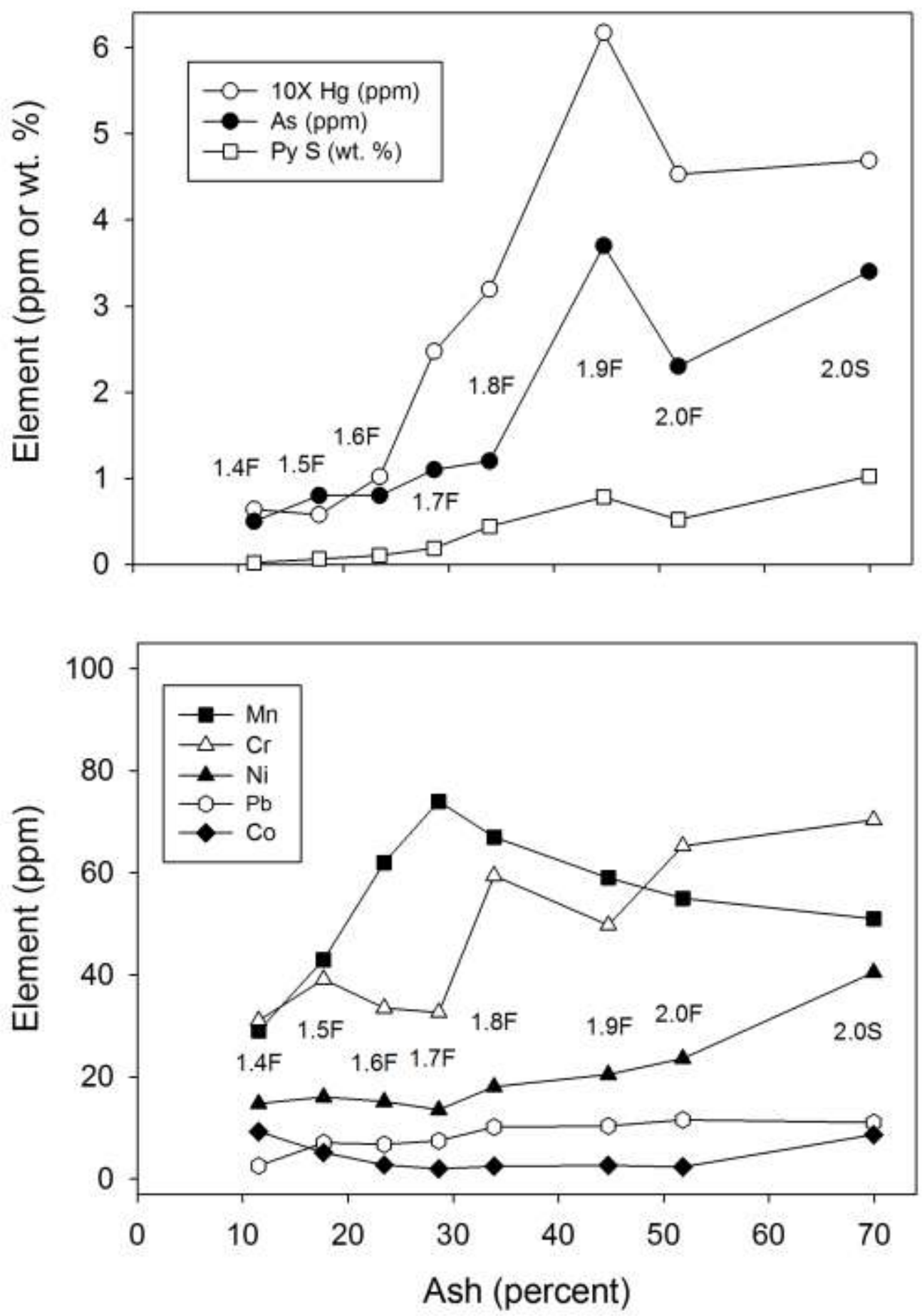

Figure 2. Plot showing increase in mercury and arsenic in separates prepared at increasing separation densities, and corresponding increase in pyrite content (as pyritic sulfur) (upper); Partitioning of elements manganese, chromium, nickel, lead, and, cobalt (lower plot; results on a whole coal dry basis). 


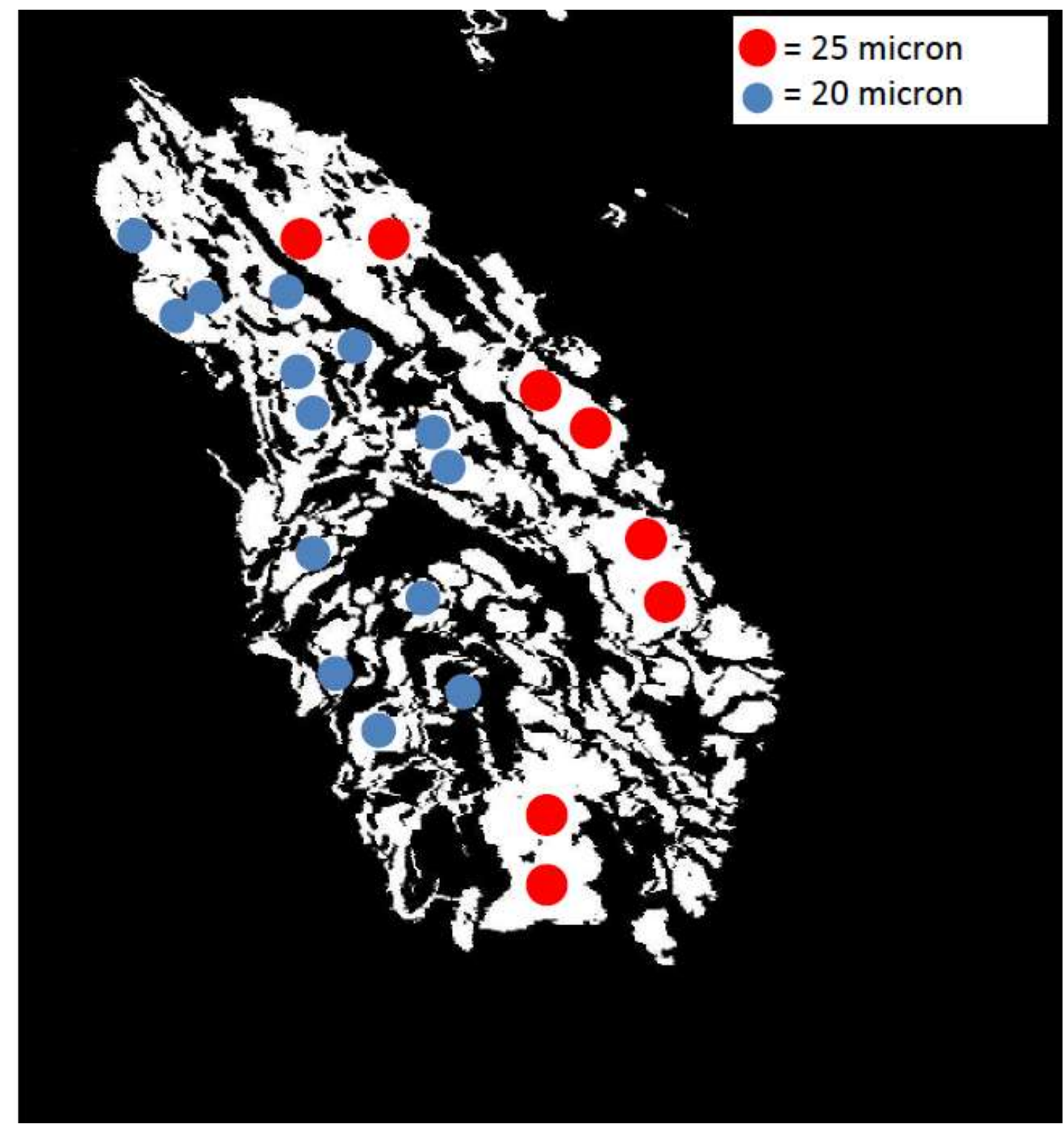

Figure 3. Backscattered electron image of a composite pyrite in density separate sample 1.9F from Highveld (\#4) coal showing laser ablation spot analysis points using 25 micrometer (red) or 20 micrometer (blue) laser diameter. Width of field-of-view is 600 micrometers. 


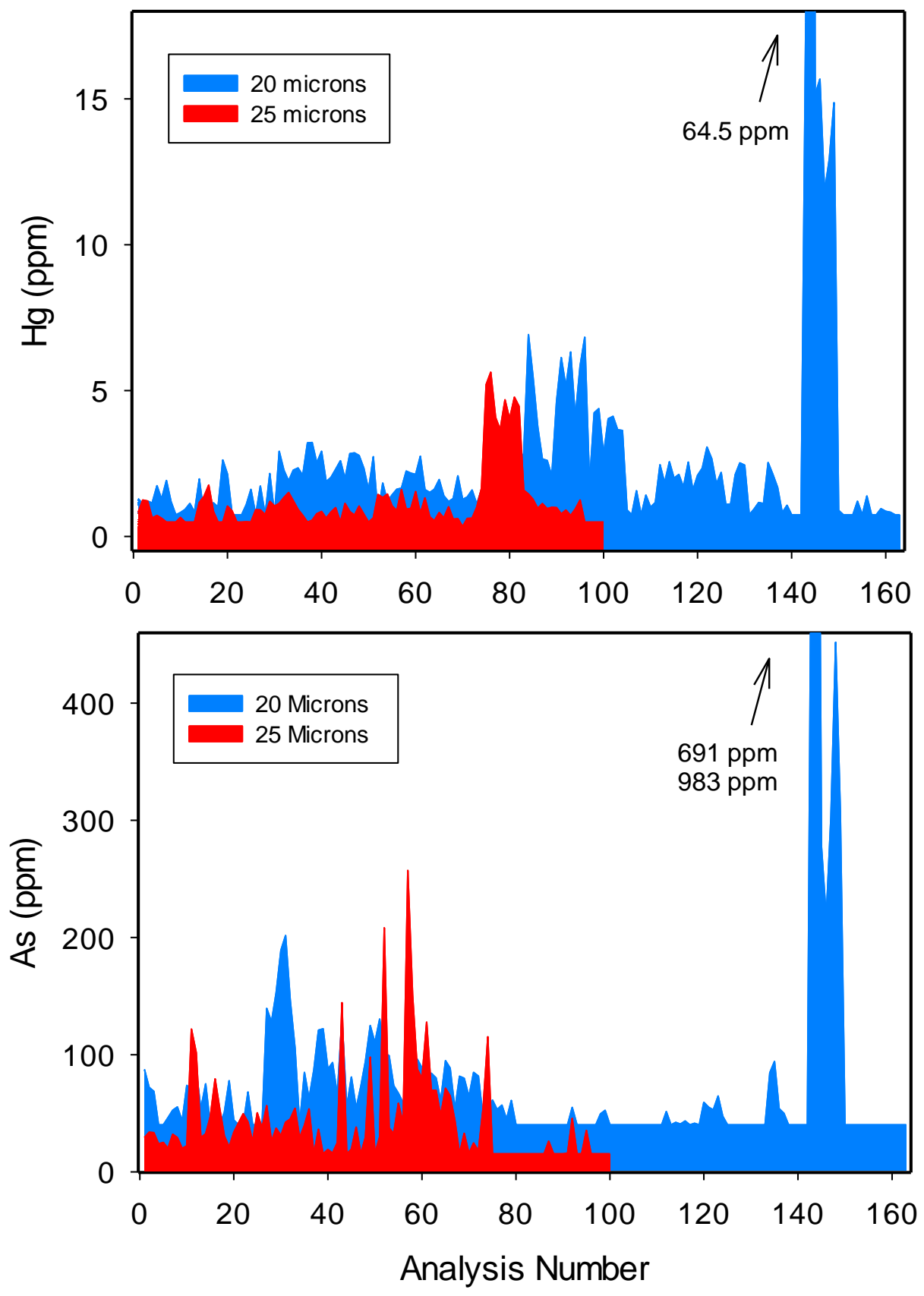

Figure 4. Laser ablation ICP-MS spot analyses for $\mathrm{Hg}$ and As in pyrite from Highveld (\#4) coal density separates showing fine-scale compositional variation. Upper plot- distribution of $\mathrm{Hg}$ in the pyrites determined. Non detects are plotted at the detection limits, $0.49 \mathrm{ppm}$ for $25 \mu \mathrm{m}$ data and $0.74 \mathrm{ppm}$ for $20 \mu \mathrm{m}$ data. Lower plot- distribution of As in the pyrites determined. Non detects are plotted at the detection limits, $15.3 \mathrm{ppm}$ for $25 \mu \mathrm{m}$ data and $40.1 \mathrm{ppm}$ for $20 \mu \mathrm{m}$ data. Comparison by analysis number shows relative enrichment of $\mathrm{Hg}$, As, or both. 